\title{
Evaluation of Methotrexate Toxicity Among Patients Presented to the Poison Control Center of Ain Shams University Hospitals, Egypt: A Prospective Study
}

\author{
Hany M. Tawfik ${ }^{1}$ and Aya S. Khater ${ }^{2}$
}

\begin{tabular}{|c|c|}
\hline & ABSTRACT \\
\hline $\begin{array}{l}\text { KEYWORDS } \\
\text { Methotrexate, } \\
\text { Mortality, } \\
\text { Therapeutic, } \\
\text { Errors, } \\
\text { Stomatitis, } \\
\text { Respiratory. }\end{array}$ & $\begin{array}{l}\text { Toxicity following acute ingestion of large amount of methotrexate is rarely } \\
\text { reported, yet accidental daily dosing of methotrexate can result in life-threatening } \\
\text { toxicity. This study aims to evaluate the outcome of cases of methotrexate toxicity } \\
\text { reported to the Poison Control Center of Ain Shams University Hospitals, Egypt with } \\
\text { highlight on causes of mortality, frequency of adverse effect and treatment offered. A } \\
\text { prospective study conducted on patients suffering from methotrexate toxicity } \\
\text { admitted to the Poison Control Center from beginning of January } 2015 \text { till the end of } \\
\text { December } 2018 \text {. Twenty-seven patients were included and were classified into two } \\
\text { groups: Survivors and non-survivors. The following variables were studied: presence } \\
\text { or absence of vomiting, diarrhea, stomatitis, dysphagia, melena, rash, respiratory } \\
\text { distress and treatment given to the patients. Venous samples were drawn for } \\
\text { complete blood picture, renal function test and liver enzymes. Electrocardiogram } \\
\text { and chest X- ray were performed for all patients on admission and repeated if } \\
\text { needed. Our results revealed that } 41 \% \text { of patients had no effect, minor effect (7\%), } \\
\text { moderate effect (4\%), and major effect ( } 22 \%) \text {. Death was reported in } 26 \% \text { of the } \\
\text { cases. The majority of patients (63\%) were due to therapeutic errors. Accidental and } \\
\text { suicidal patients were asymptomatic. Major manifestations and death were reported } \\
\text { in cases of therapeutic error. Death was mainly due to respiratory complications. } \\
\text { Errors with methotrexate treatment were the main cause of toxicity and respiratory } \\
\text { complication was the most common cause of mortality. Strategies to reduce these } \\
\text { harms are highly required. }\end{array}$ \\
\hline
\end{tabular}

Introduction

Methotrexate (MTX), a folic acid antagonist and analogue, widely used in treatment of autoimmune diseases, certain types of cancer, ectopic pregnancy and placenta accrete LoVecchio et al. (2008). It acts as a reversible inhibitor of dihydrofolatereductase (DHFR) and thymidylate synthase Hannah et al. (2017). Methotrexate blocks the

\footnotetext{
(1) Poison Control Center, Faculty of Medicine, Ain Shams University Hospitals.

(2) Forensic Medicine and Clinical Toxicology Department, Faculty of Medicine, Ain Shams University.
}

synthesis of tetrahydrofolate from dihydrofolate leading to inhibition of DNA synthesis, impairment of cellular replication and repair Vikhyat et al. (2014) particularly in rapidly proliferating cells, such as cancer or immune cells Wang (2015). Unfortunately, the effects of MTX extend also to the healthy normal cells resulting in toxicity (LoVecchio et al., 2008). Oral absorption appears to be dose dependent; MTX is generally absorbed at doses $30 \mathrm{mg} / \mathrm{m}^{2}$, with a mean bioavailability of 60-70\%. While, at doses approaching 80 $\mathrm{mg} / \mathrm{m}^{2}$, its absorption is as low as $20 \%$, which is due to enzyme saturation (Sinicina et al., 2005). Therefore, large oral dose doesn't 
increase serum levels and toxic level $>10$ mol/L can't be reached (LoVecchio et al., 2008). While, administration of MTX parentally results in rapid, complete absorption and higher serum levels (Bello et al., 2017). The recommended starting dose for patients with rheumatoid arthritis, according to the full prescribing information, is a single oral dose of $7.5 \mathrm{mg}$ once weekly or divided to $2.5 \mathrm{mg}$ every 12 hours for three doses per week. The dosing schedule may be adjusted to achieve optimal response, with doses up to $25 \mathrm{mg}$ weekly. Severe toxicity following an acute ingestion of a large amount of MTX is rarely reported (Isoardi et al., 2018). Most errors were due to accidental daily dosing of oral methotrexate that was prescribed for weekly administration (Matthew., 2018). Therapeutic dosing error of MTX can result in lifethreatening toxicity including: gastrointestinal affection in the form of (dysphagia, stomatitis, esophagitis or gastrointestinal bleeding), hepatic (hepatitis), pulmonary (interstitial pneumonitis), neurologic (ataxia, nerve palsies, paraplegia and leukoencephalopathy) bone marrow suppression, sepsis and multisystem organ failure (Badurdeen et al., 2011). Toxicity following intravenous MTX therapy can be life threatening more than oral therapy. Risk factors for development of toxicity include hypoalbuminemia, renal or hepatic dysfunction, body mass index $>25 \mathrm{~kg} / \mathrm{m}^{2}$, urine $\mathrm{pH}<7$, intravenous fluid intake less than $3 \mathrm{~L} / \mathrm{m}^{2} / 24$ hours or certain concomitant medications (Mitrovic et al., 2016). Folate supplementation is usually recommended for patients receiving MTX to minimize the adverse effects of folate deficiency with weekly doses of (5- $27.5 \mathrm{mg})$. However, a pragmatic approach is the use of $5 \mathrm{mg}$ folate supplementation once weekly (Pangilian., 2011).

This study aims to evaluate the outcome associated with cases of MTX toxicity reported to the Poison Control Center of Ain
Shams University Hospitals (PCC-ASUH), Egypt with highlight on causes of mortality, frequency of adverse effect and treatment offered to them.

\section{Subjects and Methods:}

Across sectional study was conducted on patients suffering from MT toxicity admitted to the PCC-ASUH, Egypt from beginning of January 2015 till end of December 2018. The diagnosis of cases was established on the basis of reliable history of MTX intake and the clinical signs and symptoms. The grade of severity was coded according to the outcome criteria of the American Association of Poison Centers National Poison Data System as: (No effect, Minor, Moderate, Major and Death) Bronstein et al. (2008). "No effect" if the patient did not develop any symptoms or signs after the exposure. "Minor effects" are signs or symptoms due to the exposure, but were minimally bothersome and generally resolved rapidly with no residual disability or disfigurement. "Moderate effects" are signs or symptoms as a result of the exposure that were more pronounced, more prolonged or more systemic in nature than minor symptoms and required treatment. Symptoms were not lifethreatening and the patient had no residual disability or disfigurement. "Major effects" are signs or symptoms as a result of the exposure that were life threatening or resulted in significant residual disability or disfigurement (as status epilepticus or repeated seizures, respiratory compromise which required intubation, ventricular tachycardia with hypotension, cardiac or respiratory arrest, esophageal stricture and disseminated intravascular coagulation). "Death" if the patient died as a result of the exposure or as a direct complication of exposure.

Twenty-seven patients were included in our study and were classified according to their outcome into two groups with MTX 
toxicity: Survivors included 20 patients and non-survivors included 7 patients. All patients were subjected to full history taking (including age, gender, circumstances of poisoning and history of medical diseases), physical examination (including regular monitoring of vital signs, general and local examination). The following dependent variables were studied: presence or absence of vomiting, stomatitis, dysphagia, diarrhea, melena, rash, respiratory distress and treatment giving to them including (folinic acid, colony stimulating factor, mechanical ventilation, blood product transfusion and hemodialysis). Venous samples were drawn under aseptic conditions for analysis of complete blood picture, renal function and liver enzyme. Electrocardiogram (ECG) and chest X- ray were done for all patients at admission and repeated if needed.

Conventional treatment included gut decontamination via gastric lavage and activated charcoal for patients admitted within four hours of ingestion.

Symptomaticpatients received folinic acid parental if available.

Patients with neutropenia (cells counts $<$ $1000 /$ microL) received colony stimulating factor if available withprophylactic parental antibiotic and antifungal.

Patients with haemorrhage, bleeding disorders, or thrombocytopeniawere all treated with blood products transfusion.

Patients with persistent nausea and vomiting received intravenous fluid replacement and antiemetics.

Patients with respiratory distress and desaturation received $\mathrm{O} 2$ therapy and mechanicalventilation if needed.

\section{Outcomes Measures:}

Our primary outcome was to estimate the frequency and causes of mortality. Our secondary outcomes were to evaluate the frequency of adverse effect and treatment offered to them.

Exclusion criteria: History of diabetes mellitus, cardiovascular, respiratory, renal, hepatic diseases, leucopenia or thrombocytopenia and unreliable history were excluded from the study.

\section{Ethical Considerations:}

Informed written consent was obtained from either patients or their guardian if patients were in severe conditions. Approval of the Ethics Committee of Faculty of Medicine was obtained. All information gathered was anonymized and securely protected. Data were only available to the investigators.

\section{Statistical analysis:}

Data were analyzed using IBM SPSS 22 statistical software. The categorical data were reported in number and percentage and continuous data were reported as meanand standard deviation. The difference of frequency between two groups was analyzed by chi square test for categorical data and by ttest for continuous data. $\mathrm{P}$ value less than 0.05 was considered statistically significant.

\section{Results}

Twenty-seven patients met our inclusion criteria of methotrexate toxicity. The majority of exposure was due to therapeutic error $(63 \%)$ and $(56 \%)$ were by parental route as shown in figures (1 and 2). 


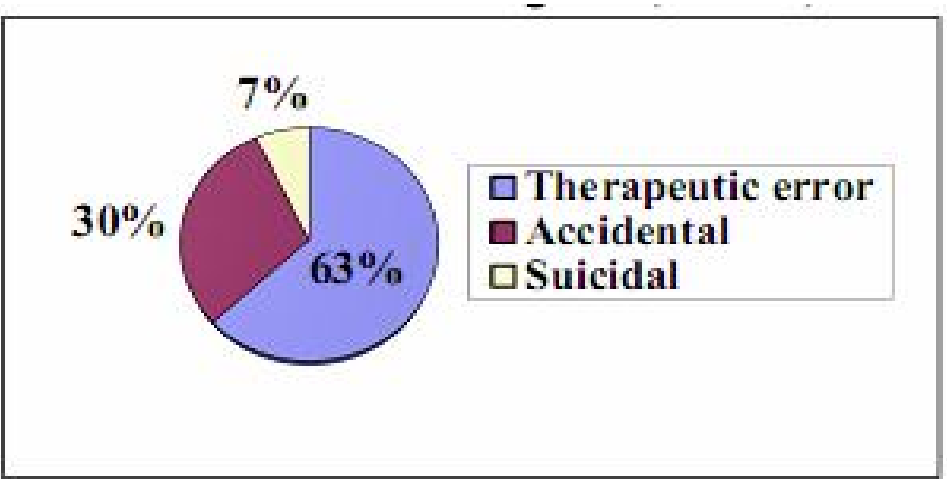

Fig. (1): Circumstances of poisoning of the studied patients $(n=27)$

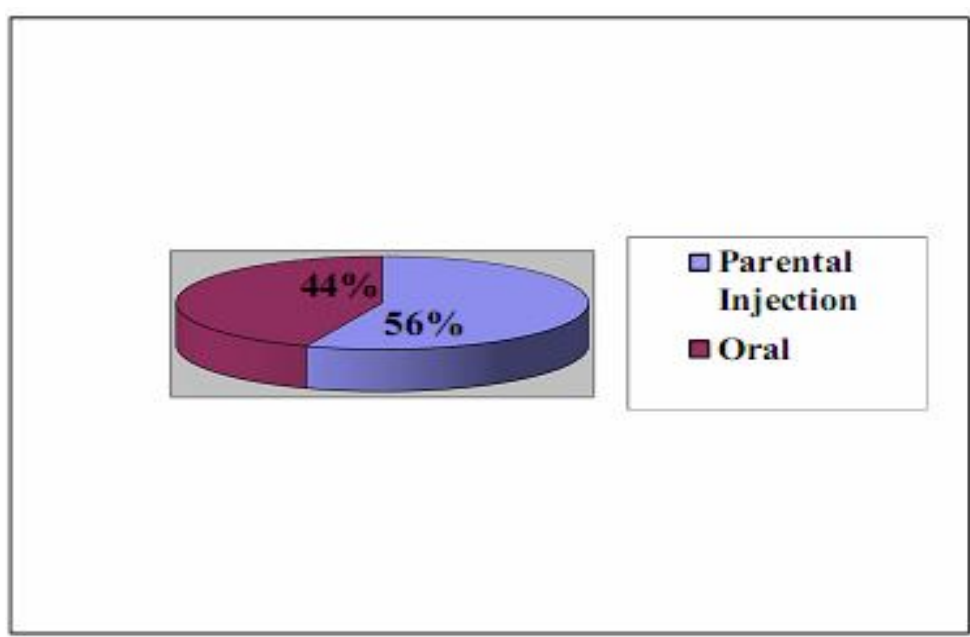

Fig. (2): Route of poisoning of the studied patients $(\mathrm{n}=27)$.

Twenty two percent had major manifestation and mortality rate was (26\%) as shown in figure (3).

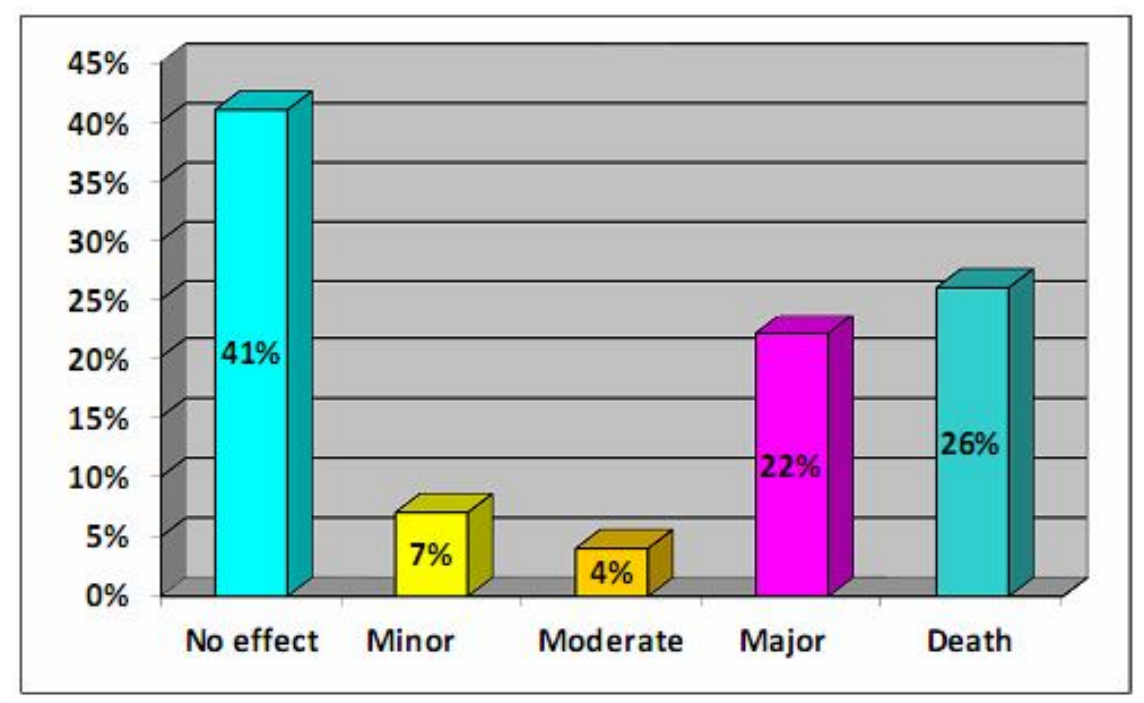

Fig. (3): Grade of severity of the studied patients $(n=27)$. 
On analysis of the clinical manifestation and the delay time until manifestation, it was found that patients with presentation to the hospital was longer (mean therapeutic error whom only developed $5 \pm 2$ days) than other patients (Table 1 ).

Table (1): Manifestation and delay time as regards the circumstances of toxicity

\begin{tabular}{|l|c|c|c|c|}
\hline \multicolumn{1}{|c|}{ Circumstances } & Number & Symptomatic & Asymptomatic & Delay Time \\
\hline Therapeutic error & 17 & 16 patients & 1 patient & $5 \pm 2$ days \\
\hline Accidental & 8 & 0 & 8 patients & $2 \pm 1$ hour \\
\hline Suicidal & 2 & 0 & 2 patients & $2 \pm 1$ hour \\
\hline
\end{tabular}

Fifty two percent of the patients were males and there was significant increase in age among the nonsurvivors (Table 2).

Table (2): Classification of gender and age of the studied patients

\begin{tabular}{|c|c|c|c|c|c|}
\hline & Survivors & Non-Survivors & Total & & \\
\hline Number & 20 & 7 & 27 & & \\
\hline \multicolumn{4}{|c|}{ Gender } & Chi square & $\mathrm{p}$ \\
\hline Female & 11 & 2 & $13(48 \%)$ & \multirow{2}{*}{1.5} & \multirow{2}{*}{0.2} \\
\hline Male & 9 & 5 & $14(52 \%)$ & & \\
\hline \multicolumn{4}{|c|}{ Age } & $\mathrm{t}$ & $\mathrm{p}$ \\
\hline Mean age/ year & $28 \pm 25$ & $51 \pm 16$ & $34 \pm 25$ & 2.1 & $0.04^{*}$ \\
\hline
\end{tabular}

*Significant

Respiratory complication was the main cause of death (5 of 7 patients) as shown in figure (4).

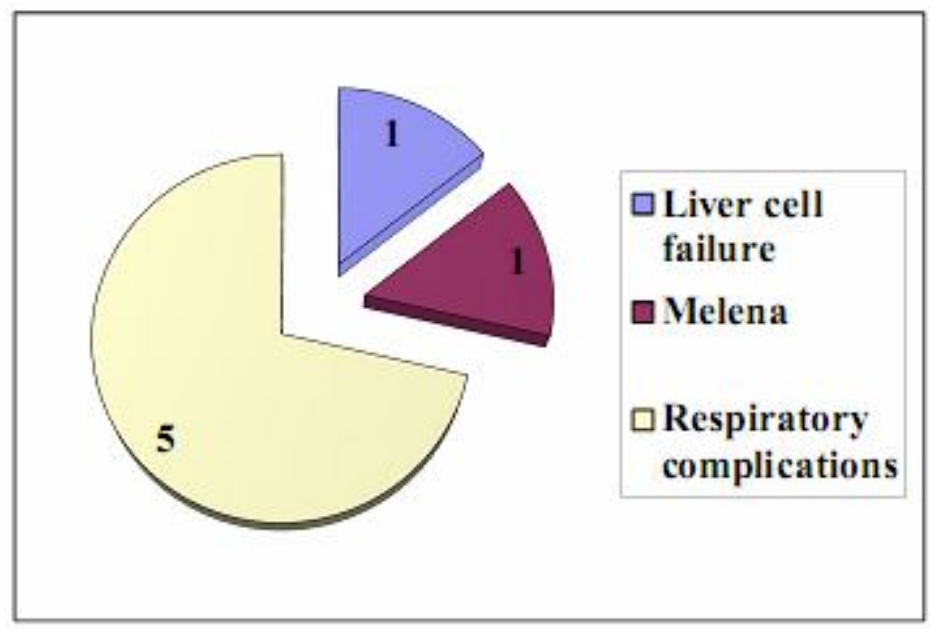

Fig. (4): Cause of death among non-survivors $(n=7)$ 
There was significant increase in stomatitis, dysphagia, respiratory distress, skin rash, diarrhea, melena and CNS manifestations among the non survivors as shown in table (3).

Table (3): Most frequent reported symptoms and signs for the two studied groups

\begin{tabular}{|l|c|c|c|c|c|}
\hline \multicolumn{1}{|c|}{ Symptoms/Signs } & $\begin{array}{c}\text { Survivors } \\
(\mathbf{n}=\mathbf{2 0})\end{array}$ & $\begin{array}{c}\text { Non-survivors } \\
(\mathbf{n}=\mathbf{7})\end{array}$ & $\begin{array}{c}\text { All } \\
(\mathbf{n}=\mathbf{2 7})\end{array}$ & Chi square & $\mathbf{p}$ \\
\hline Stomatitis & $6(30 \%)$ & $5(71 \%)$ & $11(41 \%)$ & 3.7 & $0.05^{*}$ \\
\hline Dysphagia & $6(30 \%)$ & $5(71 \%)$ & $11(41 \%)$ & 3.7 & $0.05^{*}$ \\
\hline Vomiting & $4(20 \%)$ & $3(43 \%)$ & $7(26 \%)$ & 1.4 & 0.2 \\
\hline Respiratory distress & $0(0 \%)$ & $7(100 \%)$ & $7(26 \%)$ & 27 & $0.0001^{*}$ \\
\hline Skin rash & $2(10 \%)$ & $4(57 \%)$ & $6(22 \%)$ & 6.7 & $0.01^{*}$ \\
\hline Diarrhea & $2(10 \%)$ & $4(57 \%)$ & $6(22 \%)$ & 6.7 & $0.01^{*}$ \\
\hline Melena & $1(5 \%)$ & $4(57 \%)$ & $5(19 \%)$ & 9.3 & $0.002^{*}$ \\
\hline CNS & $0(0 \%)$ & $2(29 \%)$ & $2(7 \%)$ & 6.2 & $0.01^{*}$ \\
\hline
\end{tabular}

$\mathrm{n}=$ number, *Significant

Concerning the investigation performed to the patients, Statistical analysis revealed significant increase in bone marrow suppression, renal affection, chest X-ray abnormalities and ECG abnormalities among the non-survivors. The ECG abnormalities were [one had ischemic changes, two had atrial fibrillation and one had supra ventricular tachycardia] (Table 4).

Table (4): Laboratory, chest X-ray and ECG results of the two studied groups

\begin{tabular}{|l|c|c|c|c|c|}
\hline \multicolumn{1}{|c|}{ Investigation } & $\begin{array}{c}\text { Survivors } \\
(\mathbf{n = 2 0})\end{array}$ & $\begin{array}{c}\text { Non-survivors } \\
(\mathbf{n = 7})\end{array}$ & $\begin{array}{c}\text { All } \\
(\mathbf{n = 2 7})\end{array}$ & Chi square & P \\
\hline $\begin{array}{l}\text { CBC: Bone marrow } \\
\text { suppression }\end{array}$ & $6(30 \%)$ & $7(100 \%)$ & $13(48 \%)$ & 10.2 & $0.001^{*}$ \\
\hline Renal impairment & $1(5 \%)$ & $5(71 \%)$ & $6(22 \%)$ & 13.2 & $0.0002^{*}$ \\
\hline Liver impairment & $1(5 \%)$ & $1(14 \%)$ & $2(7 \%)$ & 0.7 & 0.4 \\
\hline $\begin{array}{l}\text { Chest X-ray } \\
\text { abnormalities }\end{array}$ & $0(0 \%)$ & $5(71 \%)$ & $5(19 \%)$ & 17.5 & $0.00003 *$ \\
\hline ECG abnormalities & $0(0 \%)$ & $4(57 \%)$ & $4(15 \%)$ & 13.4 & $0.0002^{*}$ \\
\hline
\end{tabular}

ECG: electrocardiography, $\mathrm{n}=$ number, *Significant

As regards the treatment offered to the patients there was significant increase in the use of folinic acid, colony stimulating factor, blood products transfusion and mechanical ventilation among the non-survivors (Table 5). 
Table (5): Treatment offered for the two studied groups

\begin{tabular}{|l|c|c|c|c|c|}
\hline \multicolumn{1}{|c|}{ Treatment } & $\begin{array}{c}\text { Survivors } \\
(\mathbf{n = 2 0})\end{array}$ & $\begin{array}{c}\text { Non-survivors } \\
(\mathbf{n}=7)\end{array}$ & $\begin{array}{c}\text { All } \\
(\mathbf{n}=\mathbf{2 7})\end{array}$ & $\begin{array}{c}\text { Chi } \\
\text { square }\end{array}$ & $\mathbf{p}$ \\
\hline Folinic acid ampoule & $9(45 \%)$ & $7(100 \%)$ & $16(59 \%)$ & 6.5 & $0.01^{*}$ \\
\hline $\begin{array}{l}\text { Colony-stimulating } \\
\text { factor }\end{array}$ & $3(11 \%)$ & $6(86 \%)$ & $9(33 \%)$ & 11.7 & $0.0006^{*}$ \\
\hline $\begin{array}{l}\text { Blood-product } \\
\text { transfusion }\end{array}$ & $1(4 \%)$ & $6(86 \%)$ & $7(26 \%)$ & 17.6 & $0.00002^{*}$ \\
\hline Mechanical ventilation & $0(0 \%)$ & $5(71 \%)$ & $5(19 \%)$ & 17.5 & $0.00002^{*}$ \\
\hline Hemodialysis & $0(0 \%)$ & $1(14 \%)$ & $1(4 \%)$ & 3 & 0.08 \\
\hline
\end{tabular}

$\mathrm{n}=$ number, *Significant.

\section{Discussion:}

Methotrexate has been established as the most commonly used disease modifying antirheumatic drug required for the treatment of rheumatoid arthritis and autoimmune disease (Weinblatt, 2004). It is preferably prescribed as a weekly dose due to its effectiveness and low cost. However, any dosing regimen may induce toxicity and high doses can be fatal (Kivity et al., 2014).

Our results revealed no significant differences as regard gender with significant increase of age among non-survivors. Mortality rate was $26 \%$ and $63 \%$ were due to therapeutic errors. Also, our study revealed that most of the patients died due to respiratory complication (5 of 7 patients). All accidental and suicide patients were asymptomatic, while the non-survivors and those whom had major manifestation were due to therapeutic error.

Similar results were obtained by Lim et al. (2005) in their study on 25 patients with pancytopenia due to MTX toxicity where the mortality rate was $28 \%$. Similarly, Goldsmith and Roach (2007) in a study of medication errors reported to the Food and Drug Administration over 4 years found more than 100 cases of MTX dosing errors with 25 deaths, of which $37 \%$ were attributed to the prescriber, $20 \%$ to the patient, $19 \%$ to dispensing and $18 \%$ due to administration by a health care professional. Moreover, the National Coronial Information System (NCIS) dataset reported 12 cases that died due to MTX with dosing errors were detected in 7 cases receiving the drug for duration between 3 and 10 consecutive days.

The NCIS database concluded that taking MTX for 3 consecutive days can be fatal (Schmiegelow 2009). In addition, Moore et al. (2004) published a study of MTX dosing error over a period of four years which resulted in 25 deaths and 48 serious outcomes that were all due to daily dosing. Vikhyat et al. (2014) in a study performed on 42 cases of MTX toxicity found that the mean age of their patients was 49 years, $21 \%$ were suicide attempts and $17 \%$ of their cases were males. The authors also reported that $22 \%$ of the patients had no effect, $73 \%$ had minor effect, $2.5 \%$ had moderate effect and major effect was found in $2.5 \%$.

In contrast to the current study they didn't report any deaths among their cases. Moreover, LoVecchio et al. (2008) found that the average age of their patients was 43 years and that acute accidental and suicidal oral MTX exposures were mainly asymptomatic so they didn't require folinic acid rescue. This could be explained that higher oral doses don't directly correlate with respective increase in 
serum levels. While the potentially lifethreatening effects of toxicity from chronic exposures of MTX are documented in patients receiving IV or parenteral treatment.

In contrast, Aslibekyan et al. (2014) found that proportion of Poison Information Centers reported patients took the drug daily for weeks before they presented to hospital with no serious effect and concluded that such diversity of response could be caused by the marked variability in genes involved in MTX absorption, transport, metabolism and excretion. Kivity et al. (2014) stated that the usual cause of MTX-related mortality is respiratory complication mainly pneumonitis, which can occur idiosyncratically even after one dose and bone marrow suppression is another cause of mortality, multiple organ failure and gastrointestinal bleeding occurring secondary to this.

Our results revealed that $41 \%$ of patients were presented with stomatitis and dysphagia, while other gastrointestinal symptoms as vomiting, diarrhea and melena represented in $26 \%, 22 \%$ and $19 \%$ respectively. Also, $26 \%$ of the patients were presented by respiratory distress and $22 \%$ had skin rash. Similarly, Salliot and Van der Heijde (2009) found that gastrointestinal toxicities were most frequent, with a prevalence of $20-65 \%$, and are usually characterized by different severity (e.g., nausea, vomiting, diarrhea, abdominal pain and melena). Basch et al. (2011) reported emesis among $10-30 \%$ of patients receiving high dose MTX even when using appropriate antiemetic. Moreover, Saravanan and Kelly (2006) found that many series estimate that acute pulmonary toxicity develops in $1-8 \%$ of patients receiving MTX for rheumatologic condition, but some reports suggested an incidence as high as $33 \%$. On the other hand, D'Elia (2014) reported lower percent of pulmonary toxicity $(0.5 \%)$ because not all cases of pneumonitis occurring in patients treated with MTX were directly attributable to the drug. In addition, Avinash (2017) found that $14-15 \%$ of patients developed a nonspecificmorbilliform drug rash in the form of erythematous, macular, pruritic and often confined to the neck and trunk, which can be photosensitive. In addition, less severe manifestations were documented by Vikhyat et al. (2014) where they found that $2.3 \%$ had rash, $2.3 \%$ had diarrhea and no patients developed seizure, lethargy, vomiting or dysrhythmia. On the other hand, Scott et al. (2016) found higher CNS events (11\%) and including confusion, seizures, somnolence and headache with or without the presence of radiographic evidence of leukoencephalopathy.

The laboratory results of the current study revealed that $48 \%$ of the patients had bone marrow suppression, $22 \%$ had renal impairment and $7 \%$ had liver affection. Similarly, the National Coronial Information System (NCIS) reported that MTX was listed as a cause of death, including 12 cases documented with bone marrow suppression (Rose et al., 2016). Peter et al. (2017) found that the prevalence of hematologic toxicity, including thrombocytopenia, leukopenia and pancytopenia was estimated to be $2-4 \%$.

Moreover, Mori et al. (2016) reported pancytopenia in $1.4 \%$ of patients on MTX therapy which can be fatal. Lim et al. (2005) reported hematologic toxicity occuring in 3\% of patients where pancytopenia was detected in nine patients and seven were presented with bleeding (gums, urinary tract, epistaxis, vaginal or rectal). The authors also found eight patients suffered from renal impairment, three patients had abnormal liver function tests. The increase incidence of pancytopenia in our results may be attributed tonegligence of the patients for regular follow up and regular checking up their blood picture to allowearly detection of pancytopenia.

In contrast, higher liver affection was reported by Avinash (2017) who found that 
acute hepatitis may occur in 60 to $80 \%$ of patients and typically resolves spontaneously within one or two weeks. Moreover, Visser and Van der (2009) found that liver toxicity is a common concern and up to $20 \%$ of MTX users were estimated to have at least one episode of elevated serum transaminases and $3.7 \%$ had to discontinue MTX due to liver toxicity.

As regard renal affection, Scott et al. (2016) found that MTX can cause significant acute renal injury in $2-12 \%$ of patients which were attributed to crystallization of MTX in the lumen of renal tubules, leading to tubular toxicity. Also, Dunia et al. (2008) in their study performed on 31 patients presented with high dose MTX found that $6.4 \%$ of their cases developed severe acute renal failure and required hemodialysis. This was in accordance to Widemann and Adamson (2006) who reported renal dysfunction in $1.8 \%$ of patients treated with high-dose MTX.

On the other side, Vikhyat et al. (2014) found that only 2 patients had abnormal liver enzymes, no renal insufficiency or bone marrow suppression was reported which could be attributed to their study was performed on cases with oral MTX poisoning only and even both patients withabnormal liver enzymes (one of them had chronic liver disease and the other had concomitant ingestion of paracetamol). Moreover, it was a retrospective study and they postulated that some of these cases may had renal injury or required haemodialysis but the hospital and clinic medical records were not available for review, limiting conclusions on systemic findings.

Concerning the treatment offered to the patients in the current study, 59\% of cases received folate intravenous, 33\% received colony stimulating factor, $26 \%$ received blood products, and $19 \%$ required mechanical ventilation while hemodialysis was performed in $4 \%$ of cases. Similarly, Lim et al. (2005) in their study which included 25 patients with
MTX induced pancytopenia reported 18 patients were hospitalized, 9 patients required blood transfusion and 17 cases received parental folinic acid. On the other hand, Vikhyat et al. (2014) found that $14 \%$ of patients with MTX toxicity received folinic acid and they stated that no serious adverse effects were detected among them. Hemodialysis was not reported in their record.

\section{Conclusion:}

Respiratory complication was the most common cause of mortality among patients with MTX toxicity and dosing errors was the main cause of methotrexate toxicity which could be lethal. Further strategies to reduce these preventable harms are highly required.

\section{Recommendations:}

Measures to decrease errors in MTX prescription are highly required for prevention of its toxicity and can include:

- Obtaining a complete blood count, levels of serum creatinine, liver enzymes, performing chest X-ray before initiating MTX therapy and to be repeated at regular intervals during the duration of therapy.

- Prescribing the ideal dose in milligrams as well as ideal frequency of administration.

- Increase the awareness of both physicians and patients about the possible adverse effects.

- Packing folate and methotrexate together.

\section{Disclosure Statement:}

The authors report no conflict of interest.

\section{References:}

Aslibekyan, S.; Brown, E. and Reynolds, R. (2014): "Genetic variants associated with methotrexate efficacy and toxicity in early rheumatoid arthritis: results from 
the treatment of early aggressive rheumatoid arthritis". Pharmacogenomics J., 14:48-53.

Avinash, A. (2017): "Methotrexate Overdose". Int. J. Pharmacovigil., 2(1):13.

Badurdeen, S.; Kang, S. and Saravanan, M. (2011): "Accidental methotrexate ingestion in a 19-month old child". BMJ Case Reports. DOI: 10.1136/bcr.11.2010.3477.

Basch, E.; Prestrud, A. and Hesketh, P. (2011): "Antiemetics: American Society of Clinical Oncology clinical practice guideline update". J. Clin. Oncol., 29:4189-4198.

Bello, A.; Perkins, E.; Jay, R.; et al. (2017): "Recommendations for optimizing methotrexate treatment for patients with rheumatoid arthritis". Rheumatol., 9:6779.

Bronstein, A.; Spyker, D.; Cantilena, L.; et al. (2008): "2007 Annual report of the American association of poison control centers' National Poison Data System (NPDS): 25th Annual report". Clin. Toxicol., 46(10): 927-1057.

D'Elia, T. (2014): "Methotrexate-induced pneumonitis: Heterogeneity of bronchoalveolar lavage and differences between cancer and rheumatoid arthritis". Inflamm. Allergy Drug Targets., 13(1): 25-33.

Dunia, M.; Julio, G.; Yolanda, M.; et al. (2008): "Severe acute renal failure following high-dose methotrexate therapy in adults with hematological malignancies: A significant number result from unrecognized coadministration of several drugs". Nephrol. Dial. Transplant., 23: 37623766.

Goldsmith, P. and Roach, A. (2007): "Methods to enhance the safety of methotrexate prescribing". J. Clin. Pharm. Ther., 32:327-331.

Hannah, H.; Michael, C.; Henry, A.; et al. (2017): "Evaluation of toxicity after acute accidental methotrexate ingestions in children under 6 years old: 16-year multi-center review toxicology". J. Clin. Toxicol., 56(2):120-125.

Isoardi, K.Z.; Harris, K.; Carmichael, K.E.; et al. (2018): "Acute bone marrow suppression and gastrointestinal toxicity following acute oral methotrexate overdose". Clin. Toxicol., 56:12: 12041206.

Kivity, S.; Zafrir, Y. and Loebstein, R. (2014): "Clinical characteristics and risk factors for low dose methotrexate toxicity: A cohort of 28 patients". Autoimmun. Rev. BPJ., 64: 48-51.

Lim, A.; Gaffney, K. and Scott, D. (2005): "Methotrexate-induced pancytopenia: Serious and under-reported? Our experience of 25 cases in 5 years". Rheumatol., 44(8):1051-1055.

LoVecchio, K.; Katz, D. and Watts, I. (2008): "Four-year experience with methotrexate exposure". J. Med. Toxicol., 4(3):149-150.

Matthew, G. (2018): "Severe Harm and Death Associated with Errors and Drug Interactions Involving Low-Dose". Medications Errors, 43(4):191 -193.

Mitrovic, D.; Daan, J.; Touw, R.; et al. (2016): "Treatment of high dose methotrexate toxicity with glucarpidase". J. Clin. Toxicol., 6:293.

Mori, S.; Hidaka, M. and Kawakita, T. (2016): "Factors associated with myelosuppression related to low-dose methotrexate therapy for inflammatory rheumatic diseases". PLoSOne., 11(4): $\mathrm{e} 0154744$. 
Moore, T.; Walsh, C. and Cohen, M. (2004): "Reported medication errors associated with methotrexate". Am. J. Health Syst. Pharm., 61(13):1380-1384.

Pangilian, J. (2011): "Does folic acid reduce the toxicity of methotrexate". Available from:

www.medscape.com/viewarticle/588229.

Peter, R.; Vasana, S.; Adam, K.; et al. (2017): "The Hematologic toxicity of methotrexate in patients with autoimmune disorders". J. Neoplasm., 2 (1):1.

Rose, C.; Jared, A.; Ann-Maree, L.; et al. (2016): "Decade of Australian methotrexate dosing errors". MJA., 204(10): 384.

Salliot, C. and Van derHeijde, D. (2009): "Long-term safety of methotrexate monotherapy in patients with rheumatoid arthritis: A systematic literature research". Ann. Rheum. Dis., 68(7): 100-1104.

Saravanan, V. and Kelly, C. (2006): "Drugrelated pulmonary problems in patients with rheumatoid arthritis". Rheumatol. (Oxford), 45(7):787-789.

Schmiegelow, K. (2009): "Advances in individual prediction of methotrexate toxicity: A review". Br. J. Haematol., 146: 489-503.
Scott, C.; John, K.; Ching-Hon, P.; et al. (2016): "Preventing and managing toxicities of high-dose methotrexate". The Oncologist, 21:1-12.

Sinicina, I.; Mayr, B.; Mall, G.; et al. (2005): "Deaths following methotrexate overdoses by medical staff". J. Rheumatol., 32(10):2009-2011.

Vikhyat, S.; Matthew, D. and Douglas, M. (2014): "Acute methotrexate ingestions in adults: A report of serious clinical effects and treatments". J. Toxicol., http://dx.doi.org/10.1155/2014/214574

Visser, K. and Van der, D. (2009): "Risk and management of liver toxicity during methotrexate treatment in rheumatoid and psoriatic arthritis: A systematic review of the literature". Clin. Exp. Rheumatol., 27(6):1017-1025.

Wang, R. (2015): Chemotherapeutics: Methotrexate. In: Hoffman R, Howland $\mathrm{M}$, Lewin $\mathrm{N}$, et al. editors. Goldfrank's Toxicologic Emergencies, $10^{\text {th }} \mathrm{Ed}$. New York: McGraw-Hill; P.P. 689-697.

Weinblatt, M. (2004): "Rheumatoid arthritis: more aggressive approach improves outlook". Cleveland Clinic J. Med., 71(5):409-413.

Widemann, B. and Adamson, P. (2006): "Understanding and managing methotrexate nephrotoxicity". Oncologist, 11:694-703. 


\title{
تقييم سمية اليثوتريكسيت بين المرضى المقدمين لمركز مكافحة السموم بمستشفيات جامعة عين شمس ، مصر : دراسة مستقبلية المئية
}

\section{هانى محمد توفيق ؛ آية شوقي خاطر}

\author{
مركز السموم الأكلينيكى مستثفيات جامعة عين شمس

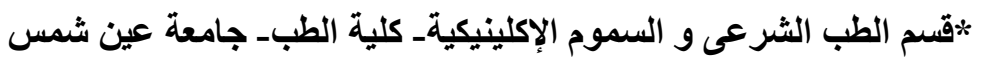

نادر ا ما يتم تسجيل التسمم الحاد بعد ابتلاع كمية كبيرة من عقار الميثونركسات، ومع ذلك فإن الجرعات اليومية منه قد تهدد الحياة. الهدف من الدراسة: تهدف هذه الدراسة الى تقييم نتائج حالات التسمم بعقار الميثوتركسات المستقبلة بمركز علاج التسمح بمستشفيات جامعة عين شمس بمصر مع تسليط الضوء على اسباب الوفاة ومدى تكرار حدوث الآثار السلبية و العلاج المقدم للمرضى. الطريقة: هذه دراسة مستقبلية على المرضى الذين يعانون من التسمم بعقار الميثوتركسات و الذين تم ادخالهم المركز من بداية يناير 10 • ب حتى نهاية ديسمبر 11 ا. ب. و اشتملت الدراسة على سبعة وعثرون مريضا وتم تقسيمهم الى مجموعة الاحياء ومجمو عة المتوفيين. تمت در اسة المتغيرات التالية: وجود او عدم وجود قيء، اسهال، التهابات بالفم، صعوبة في البلع، طفح جلدي وصعوبة في التنفس. تم سحب عينات دم وريدية لعمل صورة دم، وظائف كبد وكلى وتحليل الغاز ات بالدم. كما تم عمل رسم قلب واشعة سينية علي الصدر لجميع المرضى وتكر ارها عند اللزوم . النتائج: أظهرت النتائج أن اء؟٪ من المرضى كانوا لا يعانون من أعر اض و \٪ من المرضى كانوا بعانون من تسمم خفيف بينما ؟ ٪ من المرضى كانو ا يعانون من تسمم متوسط ، و Y Y ٪ منهم كانو ا يعانون من تسمم شديد.

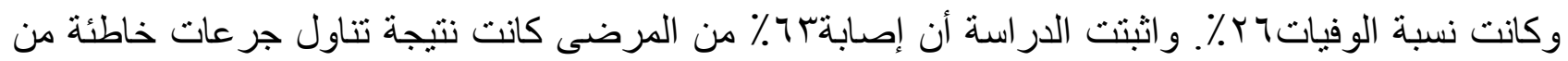
العقار بينما التسمح نتيجة الانتحار أو المصادفة لم يتسبب في حدوث أعر اض مرضية. وايضا اثبتت الدراسة ان حالات التسمم الثديدة والوفيات كانت نتيجة تتاول جرعات خاطئة وان مضاعفات اعتلال الجهاز التنفسي هي السبب الاساسي للوفاة.

الخلاصة: اثتتت الدراسة ان التسمم بعقار الميثوتركسات كان نتيجة خطأ في جرعات العلاج وان مضاعفات الجهاز التنفسي هي السبب الاكثر شيو عا للوفاة ولهذا يتطلب وجود استر اتيجيات جديدة للحد من هذا 